\title{
VÁNDORLÁSOK VIZSGÁLATA A SZEGEDI AGGLOMERÁCIÓ EGYIK TELEPÜLÉSÉN, 2010-BEN
}

\author{
Dr. PhD Zsótér Brigitta ${ }^{1}-$ Nagy Angéla ${ }^{2}$ \\ ' föiskolai docens, Szegedi Tudományegyetem Mérnőki Kar, Szeged \\ ${ }^{2}$ végzett hallgató, Szegedi Tudományegyetem Mérnöki Kar, Szeged
}

\begin{abstract}
SUMMARY
A questionnaire survey was made on the migration to Deszk from which it can be concluded that the younger and middle-.aged age group move to the settlement $(65,19 \%$ migrated from Szeged). The reasons from migration are the low prices of plots and real estates and the peaceful environment. Most of the migrants work in Szeged and they used the settlement as a so-called „bedroom community". A significant number of respondents (239 persons) drive to work. According to the analysis made by data of $\mathrm{KSH}$, in the examined period (1999-2008) mortality exceeded birth rate, the number of marriages exceeded the number of divorces. It can also be seen that more people migrate to Szeged and its catchment area than leave it.
\end{abstract}

Kulcsszavak: belsö-, nemzetközi vándorlás, migráció, legáli, illegális megráció, szegedi agglomeráció, deszki 2000 és 2010 közötti migráció, betelepülés okai

\section{BEVEZETÉS}

Közigazgatási szempontból a migráció a potenciális munkaerő nemzetállamokon belüli szabad, többé-kevésbé rendszeres és céltudatos áramlása (Lévai I. 1993).

Földrajzi tekintetben migrációnak nevezik az egyének és csoportok állandó vagy ideiglenes lakóhely-változtatását (Johnston, R. J. 2000).

A migráció általános fogalma alatt értjük azt a folyamatot, melynek során egyes személyek, vagy csoportok úgy váltanak lakókörnyezetet, illetve társadalmat, hogy ez a váltás ideiglenesből tartóssá válik.

A demográfiával foglalkozó szakirodalom szerint a migráció olyan egyensúlyra törekvő folyamat, amely két eltérő társadalmi környezettel rendelkező földrajzi pont között jön létre. Ennek során kölcsönhatás alakul ki a változó tartalmú emberi igények és környezeti adottságok között, a hosszabb távon kialakitandó összhang céljából, amelynek egyéni szintü hordozója az ember (L. Rédei M. 2001).

A migrációval foglalkozó szakemberek az elmúlt körülbelül 20 évet a „vándorlás korának" nevezik (King R. 2008).

A migráció egyik csoportosítási szempontja a sok közül a térbeliség, mely szerint beszélhetünk belső, illetve nemzetközi vándorlásról. A belső vándorlás országon belüli vándorlást, míg a nemzetközi országok közötti vándorlást jelent. Egy másik szempont szerinti csoportosítás az időtartam. Ez alapján megkülönböztetünk korlátozott, vagy időszakos vándorlást, illetve tartós, vagy folyamatos vándorlást. Beszélhetünk még önkéntes és kényszervándorlásról. Kényszervándorlás alatt értjük a kiüzést, kiüritést, menekülést, telepitést, deportálást és kivonulást. A vándorlás terjedelmét tekintve két részre lehet osztani, az egyik az egyéni vándorlás, a másik pedig a csoportos vándorlás (Becsei J. 2004, Cseresnyés F. 2005).

A törvényi szabályozás szerint lehet legális és illegális migráció. Legális migráció alatt értjük azt, amikor a vándorlók nem követnek el törvénybe ütköző cselekedeteket. Az egyes törvények kijátszása, vagy egyenesen megsértése jelenti az illegális migrációt.

A vándorlás növeli, vagy csökkenti az adott terület népességének a számát, megváltoztatja az átlag életkort, a népesség nemek és más ismérvek szerinti összetételét.

A Csongrád megyében végbemenõ vándorlásokról azt lehet elmondani (2000-es adatok alapján), hogy a városból községbe vándorlók száma a legmagasabb, összesen 2517 , 
míg a legkevesebb a városból városba történő költözések száma, amely csak 907. A községből városba vándorlók száma 907, a községből községbe vándorlóké pedig 1430.

Magas a városból községbe és a községböl községbe vándorlók száma, melyböl az derül ki, hogy az emberek előnyben részesítik a nyugodt, békés környezetet a nyüzsgő városokkal szemben. Szegedröl is sokan költöznek ki a környező településekre, például Deszkre (Csatári B. 2002-2003).

Szegedre a megye lakosságának majdnem négytizede, a környező községekkel együtt pedig közel öttizede koncentrálódik. Tudjuk, hogy Szegedet Krajkó Gyula és Mészáros Rezső településföldrajzi felosztása szerint 4 részre lehet osztani: történelmi városrész, ipari zóna, lakótelepek, csatolt települések (Krajkó Gy., Mészáros R. 1990).

Alvóváros: Egy nagyváros közelében épült, városrész nagyságnyi lakótelep, amely döntően a nagyvárosban dolgozó lakosság lakóhelyéül szolgál. Az agglomerációnak az a része, amely lakóhelyfunkciót tölt be. Célja a nagyváros tehermentesítése. Olyan elővárosi település, ahonnan a lakosság nagy része naponta a városba jár dolgozni. Ezt a jelenséget ingadozásnak is szokták nevezni (Vofkori L. 2002).

A szegedi agglomeráció lakosságának kor szerinti összetétele lényeges területi eltéréseket mutat. A vándorlások következtében az idős korosztály jelenléte nőtt Szegeden, ugyanakkor a városkörnyéki települések fiatalodtak. Jelenleg igen magas a gyermekkorúak aránya a vizsgált településen, Deszken, ezen kívül Újszentivánon és Zsombón, míg a határ menti Röszkére, Kübekházára és Szatymazra az időskorúak kiemelkedő túlsúlya jellemző.

A területi különbségeket még jobban érzékelteti az öregedési index, amely a 65 éven felüli népesség arányát fejezi ki a 15 éven aluliakhoz képest. Az agglomeráción belül 2003 elején a két pólust Zsombó, illetve Röszke és Szeged képviseli: míg Zsombón 100 gyermekre 50 idős személy jutott, addig Röszkén és Szegeden ennek az értéknek megközelitőleg a duplája.

A népesség iskolai végzettsége javult az elmúlt évtizedekben. Föleg az érettségivel és a felsőfokú végzettséggel rendelkezők költöznek ki a városokból a környékbeli településekre. A kiköltözés az esetek többségében drasztikus lakásminőségbeli változásokkal is együtt jár. A legtöbb ember bérházból vagy panelházból költözik ki a város környékére. Magyarországon a saját magánház, valamint a nagyobb lakás iránti igény játszik döntő szerepet a városokból való kiköltözésben (Bajmócy P. 2003).

A deszki 2000 és 2010 közötti migrációjával kapcsolatban készitettünk felmérést a következő feltételezések igazolására, illetve megcáfolására:

1. Azt feltételezzük, hogy a fiatalabb és a középkorú korosztály költözött be Deszkre a vizsgált időszakban.

2. A betelepülők jelentős része értelmiségi, egyetemet végzettek, akiknek a havi jövedelme 100.000-200.000 Ft között van.

3. A betelepülők legalább felének 5 milliónál magasabb összegü hitele van.

4. A betelepülök legalább $60 \%$-a Szegedröl települt át.

5. A betelepülés oka az olcsó telek- és ingatlanárak, valamint a nyugodt környezet.

6. A betelepülök nagy része Szegeden dolgozik és csak ,alvóvárosnak" használja Deszket.

7. Többségük személyautóval jár be dolgozni.

8. A Szegeden dolgozók Szegeden járatják iskolába, óvodába a gyermekeiket.

9. A betelepülők több mint fele Szegeden intézi hivatalos ügyeit.

10. A betelepülök elégedettek a településsel. 


\section{ANYAG ÉS MÓDSZER}

2010 tavaszán készült kérdőíves megkérdezés Deszk újépítésü részein. Összesen 293 db kérdöívet sikerült feldolgozni. A felmérést azon helyi lakosok körében végeztük, akik 2000 és 2010 között költöztek a településre.

A kérdőiv Deszk migrációjáról összesen 12 kérdést tartalmazott. A kérdések között voltak például: Honnan, mikor és miért költözött Deszkre? Mennyire elégedett a közbiztonsággal, parkositással, az útépitéssel, a helyi kulturális rendezvényekkel, a helyi iskolával, óvodával, a helyi egészségügyi ellátással? ...stb.

\section{EREDMÉNYEK, KÖVETKEZTETÉSEK}

Az első feltételezésünk az volt, hogy a fiatalabb és a középkorú korosztály költözik be Deszkre. Ez az állitás bizonyítást nyert, ugyanis a megkérdezettek közül 192-en $(65,53 \%)$ a 18-40 év közötti korcsoportba sorolható. A beköltözöttek átlagéletkora pedig 40,97 év.

A második feltételezés szerint a betelepülök jelentős része értelmiségi, egyetemet végzett, akiknek a havi jövedelme 100.000-200.000 Ft között van. Ez nem igazolódott be, mert a felmérés során kiderült, hogy a megkérdezettek 33\%-ának van csak felsöfokú végzettsége, $52,22 \%$-uk (153 fö) fizikai munkával keresi meg kenyerét. Jövedelmük csak 50.000-100.000 Ft közé tehetö.

$\mathrm{Az}$ a hipotézis sem igazolódott be, hogy a betelepülök legalább felének 5 milliónál magasabb összegü hitele van. A legtöbben 1-5 millió Ft közötti hitelt vettek fel (1. ábra).

1. ábra: A megkérdezettek közül a hitelfelvevők az alábbi összegeket vették fel

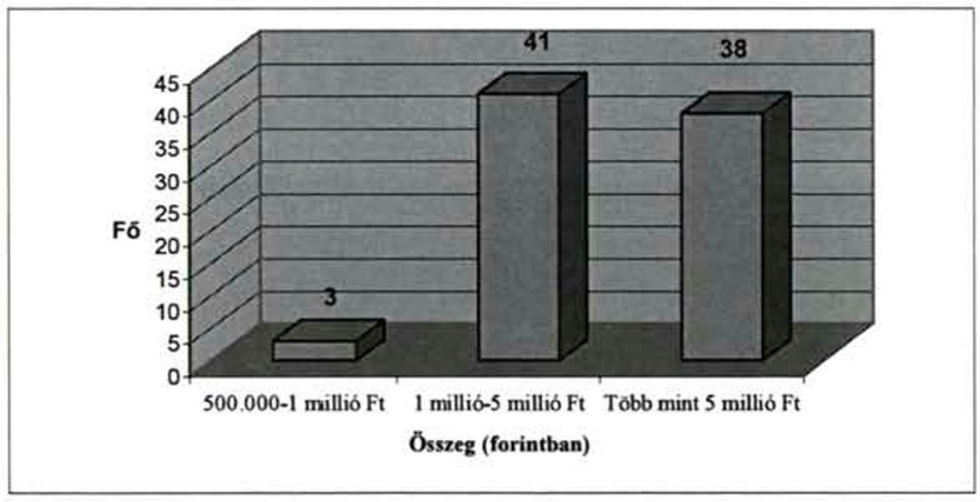

Forrás: saját kérdōíves felmérés, saját szerkesztés

A negyedik feltételezésünk, hogy a beköltözők legalább 60\%-a Szegedről települt át, beigazolódott, mivel a megkérdezettek közül 191-en $(65,19 \%)$ Szegedről és környékéröl költöztek a településre.

Az ötödik hipotézisünk is beigazolódott, miszerint a betelepülök az olcsó telek- és ingatlanárak, valamint a nyugodt környezet miatt választják Deszket. A megkérdezettek közül 110-en adták ezt a választ.

A hatodik állításunk szerint a betelepülök nagy része Szegeden dolgozik és csak ,alvóvárosnak" használja Deszket. Ez is beigazolódott, mert a megkérdezett 293 fö közül 113 -an $(47,48 \%)$ Szegeden dolgoznak.

A megkérdezettek több mint a fele (91-en 51,41\%) autóval jut el a munkahelyére (hetedik hipotézis igazolása) (2. ábra). 
2. ábra: A megkérdezettek az alábbi közlekedési eszközökkel jutnak el a munkahelyükre

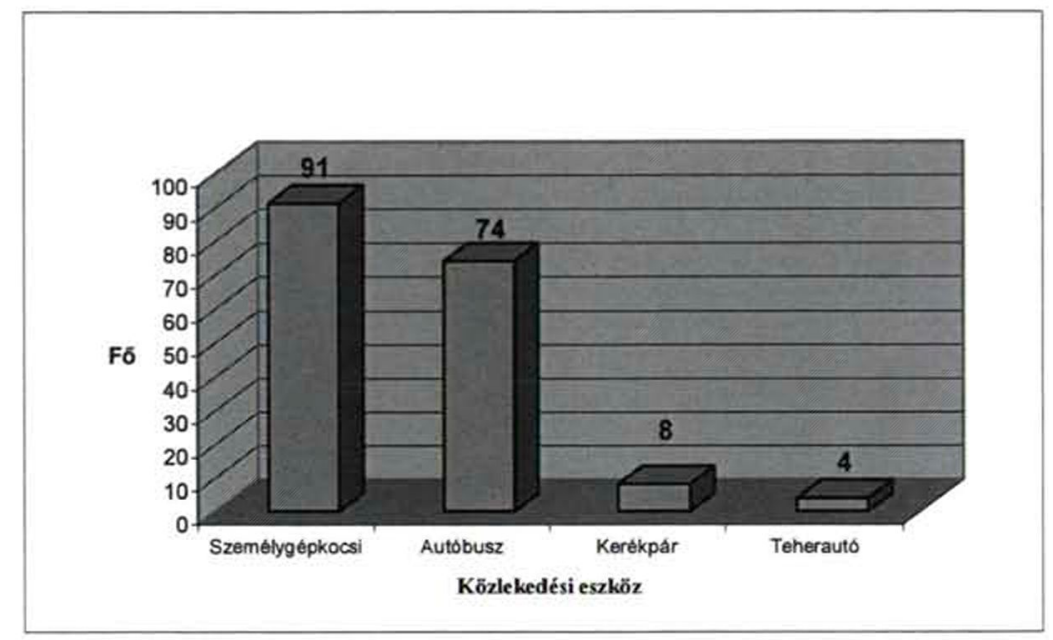

Forrás: saját kérdōives felmérés, saját szerkesztés

Az a feltételezésünk, hogy a Szegeden dolgozók Szegeden járatják iskolába, óvodába a gyermekeiket, nem igazolódott be, ugyanis a legtöbben elégedettek a deszki óvodai nevelés és iskolai oktatás színvonalával, ezért ide járatják a gyermekeiket (3. ábra).

3. ábra: A megkérdezettek gyermekei az alábbi intézményekbe járnak

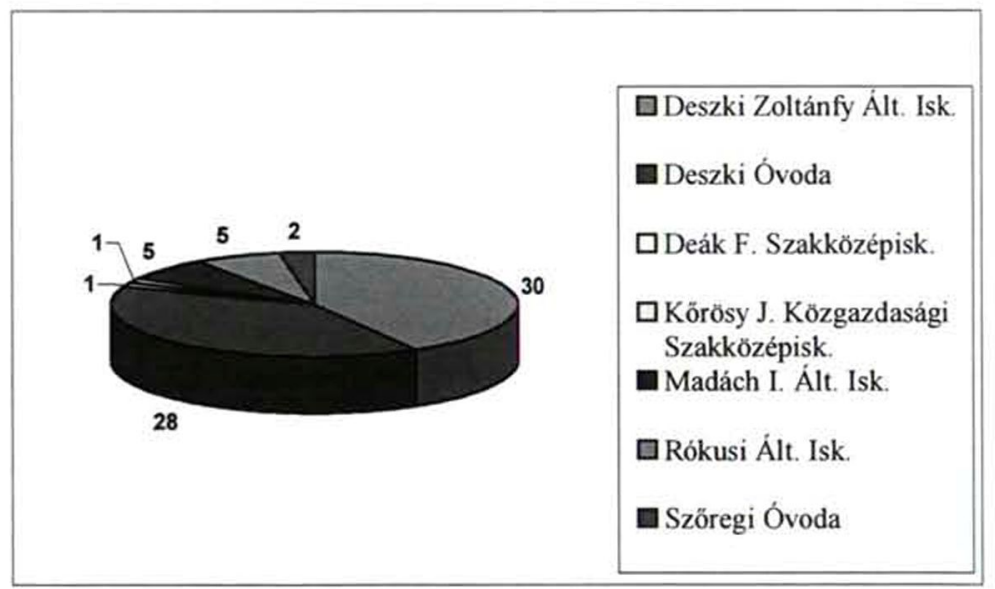

Forrás: saját kérdöíves felmérés, saját szerkesztés

Az állitottuk, hogy a betelepülök több mint fele Szegeden intézi hivatalos ügyeit. Ez sem igazolódott be, mert a megkérdezettek többsége Deszken intézi el a hivatalos ügyeit. Ezt a választ összesen 179 -en $(61,1 \%)$ adták.

Arra a kérdésre, hogy „Miért költöztek Deszkre?” különböző válaszokat kaptunk. Itt most csak a fontosabbakat említjük. 
Sokan a családjukhoz, rokonukhoz költöztek ki, összesen a megkérdezettek közül 52en (17,75\%). Sokan a panelt cserélték házra, mert csendes és nyugodt helyen akartak élni. Ezt a választ 43-an (14,68\%) adták. 110-en (37,54\%) azt válaszolták, hogy sok jót hallottak a településről, itt épitkeztek, itt vettek házat az olcsó telek és ingatlanárak miatt. A munkahely közelsége miatt is költöztek Deszkre. Ők 17-en (5,8\%) voltak. Az egyéb kategóriába soroltunk $71(24,23 \%)$ választ, amelybe az alábbiak tartoznak: ide nősült, felesége/férje/anyósa/apósa/nagyszülei idevalósi, csak egyszerüen ide akartak költözni, itt született - visszavágyott, itt kapott állást, jobb életkörülmény miatt költözött ide, örököltek egy házat (4. ábra).

4. ábra: A megkérdezettek az alábbi okok miatt hagyták ott a régi otthonaikat és költöztek Deszkre

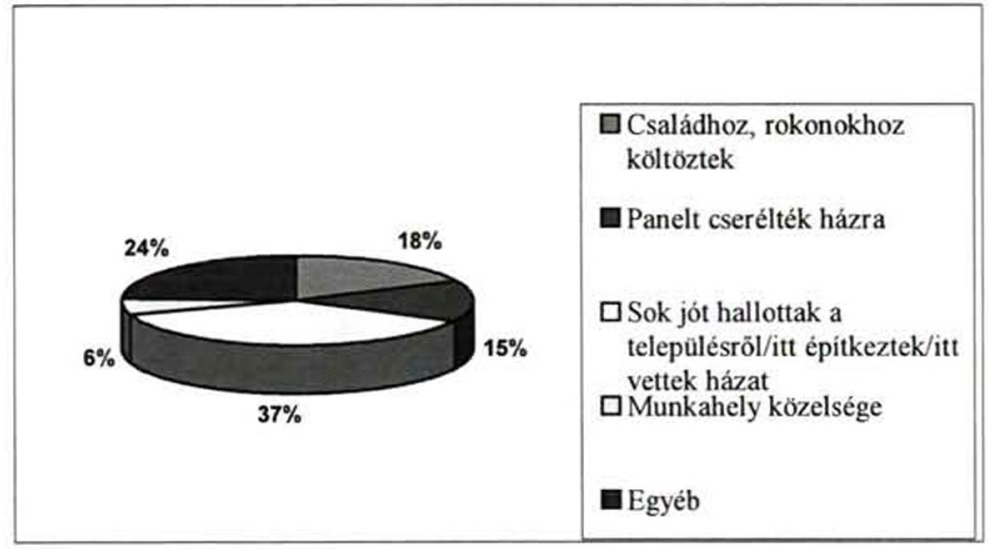

Forrás: saját kérdōives felmérés, saját szerkesztés

A megkérdezettek közül legtöbben a családjukhoz, rokonukhoz költöztek, de sokan voltak azok is, akik a községről sok jót hallottak és ennek hatására vettek, vagy épitettek házat a településen a vizsgált időszakban. táblázat.

A településsel kapcsolatos elégedettségi felmérés eredményeit tartalmazza az 1. 
1. táblázat: „Mennyire elégedett Ön az alábbiakkal?” (fö)

\begin{tabular}{|c|c|c|c|c|c|c|}
\hline & $\begin{array}{c}\text { Teljes } \\
\text { mértékben }\end{array}$ & $\begin{array}{l}\text { Nagy mér- } \\
\text { tékben }\end{array}$ & $\begin{array}{c}\text { Közepes } \\
\text { mértékben }\end{array}$ & $\begin{array}{l}\text { Kis } \\
\text { mérték- } \\
\text { ben }\end{array}$ & $\begin{array}{c}\text { Egyáltalán } \\
\text { nem }\end{array}$ & Nem tudom \\
\hline Köztisztaság & $\begin{array}{c}2 \\
(0,68 \%)\end{array}$ & $\begin{array}{c}5 \\
(1,71 \%)\end{array}$ & $\begin{array}{c}19 \\
(6,48 \%)\end{array}$ & $\begin{array}{c}95 \\
(32,42 \%)\end{array}$ & $\begin{array}{c}172 \\
(58,71 \%)\end{array}$ & 0 \\
\hline Közbiztonság & 0 & $\begin{array}{c}5 \\
(1,71 \%)\end{array}$ & $\begin{array}{c}26 \\
(8,87 \%)\end{array}$ & $\begin{array}{c}80 \\
(27,3 \%)\end{array}$ & $\begin{array}{c}182 \\
(62,12 \%)\end{array}$ & 0 \\
\hline Parkosítás & 0 & $\begin{array}{c}32 \\
(10,92 \%)\end{array}$ & $\begin{array}{c}95 \\
(32,42 \%)\end{array}$ & $\begin{array}{c}101 \\
(34,47 \%)\end{array}$ & $\begin{array}{c}65 \\
(22,19 \%)\end{array}$ & 0 \\
\hline Útépítés, járdaépítés & $\begin{array}{c}7 \\
(2,39 \%)\end{array}$ & $\begin{array}{c}75 \\
(25,6 \%)\end{array}$ & $\begin{array}{c}114 \\
(38,91 \%)\end{array}$ & $\begin{array}{c}74 \\
(25,25 \%)\end{array}$ & $\begin{array}{c}23 \\
(7,85 \%)\end{array}$ & 0 \\
\hline $\begin{array}{l}\text { Helyi kultúrális és } \\
\text { szórakozta tó } \\
\text { rendezvények }\end{array}$ & $\begin{array}{c}2 \\
(0,68 \%)\end{array}$ & $\begin{array}{c}10 \\
(3,41 \%)\end{array}$ & $\begin{array}{c}49 \\
(16,73 \%)\end{array}$ & $\begin{array}{c}156 \\
(53,24 \%)\end{array}$ & $\begin{array}{c}66 \\
(22,53 \%)\end{array}$ & $\begin{array}{c}10 \\
(3,41 \%)\end{array}$ \\
\hline Csatornázás & $\begin{array}{c}46 \\
(15,7 \%)\end{array}$ & $\begin{array}{c}150 \\
(51,19 \%)\end{array}$ & $\begin{array}{c}76 \\
(25,94 \%)\end{array}$ & $\begin{array}{c}13 \\
(4,44 \%)\end{array}$ & $\begin{array}{c}8 \\
(2,73 \%)\end{array}$ & 0 \\
\hline $\begin{array}{l}\text { Helyi közlekedés, } \\
\text { tömegközlekedés }\end{array}$ & $\begin{array}{c}1 \\
(0,34 \%)\end{array}$ & $\begin{array}{c}1 \\
(0,34 \%)\end{array}$ & $\begin{array}{c}23 \\
(7,85 \%)\end{array}$ & $\begin{array}{c}93 \\
(31,74 \%)\end{array}$ & $\begin{array}{c}165 \\
(56,32 \%)\end{array}$ & $\begin{array}{c}10 \\
(3,41 \%)\end{array}$ \\
\hline Helyi iskola, óvoda & $\begin{array}{c}87 \\
(29,7 \%)\end{array}$ & $\begin{array}{c}137 \\
(46,75 \%)\end{array}$ & $\begin{array}{c}52 \\
(17,75 \%)\end{array}$ & $\begin{array}{c}9 \\
(3,07 \%)\end{array}$ & 0 & $\begin{array}{c}8 \\
(2,73 \%)\end{array}$ \\
\hline $\begin{array}{l}\text { Helyi egészségügyi } \\
\text { ellá tás (háziorvosok, } \\
\text { fogorvos, } \\
\text { gyogyszertár) }\end{array}$ & $\begin{array}{c}108 \\
(36,86 \%)\end{array}$ & $\begin{array}{c}126 \\
(43,01 \%)\end{array}$ & $\begin{array}{c}48 \\
(16,38 \%)\end{array}$ & $\begin{array}{c}9 \\
(3,07 \%)\end{array}$ & $\begin{array}{c}1 \\
(0,34 \%)\end{array}$ & $\begin{array}{c}1 \\
(0,34 \%)\end{array}$ \\
\hline $\begin{array}{l}\text { Helyi önkormányzat } \\
\text { tevékenysége }\end{array}$ & $\begin{array}{c}124 \\
(42,32 \%)\end{array}$ & $\begin{array}{c}117 \\
(39,93 \%)\end{array}$ & $\begin{array}{c}37 \\
(12,63 \%)\end{array}$ & $\begin{array}{c}14 \\
(4,78 \%)\end{array}$ & 0 & $\begin{array}{c}1 \\
(0,34 \%)\end{array}$ \\
\hline
\end{tabular}

Forrás: saját kérdöives felmérés, saját szerkesztés

A tizedik, egyben utolsó hipotézis szerint a betelepülők összességében elégedettek a településsel. Ez a feltételezésünk igazolást nyert.

\section{4. ÖSSZEFOGLALÁS}

Végül is az első, a negyedik, az ötödik, a hatodik, a hetedik és a tizedik hipotézis beigazolódott, míg a második, a harmadik, a nyolcadik és a kilencedik feltételezés nem igazolódott be.

\section{IRODALOMJEGYZÉK}

Bajmócy P. (2003): Szuburbanizáció a budapesti agglomeráción kívüli Magyarországon. http://www.human.geo.u-szeged.hu/files/c/Bajmocy/tezis3abra.doc (2010.08.10.)

Becsei J. (2004): Népességföldrajz. Ipszilon Kiadó. Békéscsaba.

Csatári B. (2002-2003): Alföldi tanulmányok XIX. kötet: Migráció és az alföld. Nagyalföld Alapitvány. Békéscsaba.

Cseresnyés F. (2005): Migráció az ezredfordulón. Dialóg Campus Kiadó. Budapest-Pécs.

Johnston R. J. (2000): The Dictionary of Human Geography. Blackwell Publishers Ltd.. Oxford.

King R. (1993): The new geography of European migrations. Belhaven Press, London-New York.

Krajkó Gy. - Mészáros R. (1990): Az urbanizáció térbeli folyamatai Szegeden. JATE Gazdaságföldrajzi Tanszék. Szeged.

L. Rédei M. (2001): Demográfia. ELTE Eötvös Kiadó. Budapest.

Lévai I. (1993): Nemzetközi migrációs modellek: föbb típusok és trendek. MTA Társadalmi Konfliktusok Kutató Központja. Budapest. pp. 19-39.

Vofkori L. (2002): Gazdasági földrajz. Scientia Kiadó, Kolozsvár. 